\title{
Indígenas alfabetizados em português no litoral baiano setecentista: o caso de Vila de Abrantes
}

\section{Literate indians in portuguese in babian coast during the 18th century: the case of Vila de Abrantes}

\author{
Mariana Fagundes de Oliveira Lacerda* \\ Universidade Estadual de Feira de Santana \\ Feira de Santana, Bahia, Brasil \\ Zenaide de Oliveira Novais Carneiro** \\ Universidade Estadual de Feira de Santana \\ Feira de Santana, Bahia, Brasil
}

\begin{abstract}
Resumo: Apresentamos, neste trabalho - a partir da análise de documentos da fundação da Vila de Abrantes (arrolados como "Dossiê dos Índios", depositados no Arquivo Público da Bahia (Maço 603, Caderno 11)) -, evidências de mamelucos alfabetizados no litoral baiano, em meados do século XVIII, condição que os levou a assumirem cargos, entre outros, de escrivão, juiz e capitão de ordenanças do Aldeamento do Espírito Santo, que deu origem à referida Vila, no dia 18 de setembro de 1758, em ação coordenada pelo Juiz de Fora da Cidade de Salvador, João Ferreira Bittencourt e Sá. Os documentos revelam que a maioria dos indígenas entendia e falava o português na nova Vila de Abrantes, nos setecentos; poucos sabiam ler e escrever, todavia, e os que eram alfabetizados se tratavam de mestiços; oito mamelucos alfabetizados assumiram cargos na administração da Vila, havendo registros de assinatura de cinco deles em petição reivindicando terras. Para além desses fatos no litoral, apontamos aqui caminhos para o estudo da inserção do indígena na escrita portuguesa, nos sertões baianos. É possível, a nosso ver, encontrar fontes produzidas por indígenas escolarizados, a partir do século XVII, na região do semiárido, na área do Rio São Francisco e das Jacobinas e em áreas vizinhas, onde houve aldeamentos nos seiscentos e setecentos, organizados à maneira dos aldeamentos do litoral.
\end{abstract}

Palavras-Chave: Indígenas. Alfabetização. Bahia. Século XVIII.

\begin{abstract}
Based on the analysis of writing documents from the Abrantes Village Foundation (listed as "Indians Dossier", kept in the Public Archive of Bahia (roll 603, book 11), in this paper we present some evidences of literate mamelucos in Bahian coast in the middle of eighteenth century. That specific condition has leaded them to take up functions such as clerks, judges and militia captains at Espírito Santo Village, which has been named Abrantes Village by João Ferreira Bittencourt e Sá, outsider judge of Salvador City, on September 18, 1758. These documents from the eighteenth century reveal that the majority of Indians understood and spoke Portuguese at the new Abrantes Village, although few of them were able to read and write and the literate ones were mestizos. Thus, eight literate mamelucos took up administration jobs and we can find the signature of five of them in petition documents for land claims. Besides these facts, that are associated to the coastal areas, we point up the directions on the study of the insertion to the Portuguese writing by Indians, in Bahian outbacks. It's possible, in our opinion, find writing texts produced by literate Indians during the eighteenth century in the semiarid regions, specifically in São Francisco River, Jacobinas areas and nearby, where the settlement in the seventeenth and eighteenth centuries was similar to the settlement in the coastal areas.
\end{abstract}

Keywords: Indians. Literacy. Bahia. 18th Century.

* Doutora em Letras e Linguística (UFBA), professora da Universidade Estadual de Feira de Santana, Feira de Santana. E-mail: zenaide.novais@gmail.com

* Doutora em Linguística (UNICAMP), professora da Universidade Estadual de Feira de Santana. E-mail: marianafag@gmail.com. 


\title{
1 CONSIDERAÇÕES INICIAIS
}

\begin{abstract}
Repensar a história dos índios a partir da documentação textual e iconográfica que é apenas arranhada aqui significa muito mais do que simplesmente agregar mais estes ao crescente rol de 'povos sem história' que vêm sendo 'resgatados' pela historiografia ocidental. Significa reescrever capítulos inteiros da história do Brasil, para que esse novo conhecimento do passado possa lançar uma luz menos pessimista e mais justa sobre o futuro dos povos indígenas (MONTEIRO, 1994b, p.11)1.
\end{abstract}

A busca por fontes diretas em português - escritas de próprio punho pelos indígenas e mamelucos - parece enquadrar-se em um tipo de reconstrução mais "arqueológico", tendo em vista as evidências dispersas. Nos documentos da fundação da Vila de Abrantes (arrolados como "Dossiê dos Índios", depositados no Arquivo Público da Bahia (Maço 603, Caderno 11)) ${ }^{2}$, cuja análise resultou neste trabalho, há evidências de mamelucos alfabetizados, em meados do século XVIII, na criação das vilas, a partir de aldeamentos jesuítas - quando da implantação do Diretório Pombalino -, condição que os levou a assumirem cargos, entre outros, de escrivão, juiz e capitão de ordenanças do Aldeamento do Espírito Santo, que deu origem à Vila de Abrantes, no terceiro quartel do referido século, precisamente no dia 18 de setembro de 1758, em ação coordenada pelo Juiz de Fora da Cidade de Salvador, João Ferreira Bittencourt e Sá.

A reunião de pistas que indiquem uma possível inserção de indígenas e mamelucos na cultura escrita foi iniciada por Carneiro e Almeida (2007 [2002] e CARNEIRO (2009, 2011, 2013). Uma dessas pistas foi extraída nas pesquisas feitas em 2002, nos catálogos do Arquivo Histórico Ultramarino (AHU), que disponibiliza centenas de documentos históricos do Brasil Colonial, via Projeto Resgate de Documentação Histórica Barão do Rio Branco; entre esses documentos, encontra-se o requerimento de solicitação de professores feito por indígenas provenientes do antigo Aldeamento do Espírito Santo, demonstrando o interesse de seus habitantes pela escolarização:

1758, Dezembro, 9, Bahia - CONSULTA do Conselho Ultramarino ao rei D. José sobre os requerimentos dos índios moradores da Vila da Nova Abrantes, solicitando professores ${ }^{3}$, ajuda de custo para vestuário, funcionários administrativos e judiciários, reformas de antigos prédios jesuíticos, etc. Anexo: consulta (2a via). AHU Baía (Cx. 146, Doc. 40; cx. 147, Doc. 85/AHU ACL CU 005; Cx. 138, Doc. 106.675).

\footnotetext{
${ }^{1}$ Sobre a atuação dos índios e a revisão de sua participação na história do Brasil, cf., ainda, Monteiro (1992, 1994a, 1995, 2001).

${ }^{2}$ Esses documentos foram fotografados ainda em 2008, durante a prospecção de fontes para o Projeto Vozes do Sertão em Dados: história, povos e formação do português brasileiro (CNPq) e, adicionalmente, com base nas pesquisas realizadas por Luciano Brunet (2008) e Fabricio Lyrio dos Santos (2002), a quem agradecemos pelas valiosas indicações de fontes. Parte dessa documentação está sendo editada por Maria Ionáia de Jesus Souza, com vistas à elaboração de seu projeto de doutoramento, em continuação ao trabalho iniciado no seu Mestrado, intitulado Edição e estudo de documentos da Capitania da Babia do século XVIII, no qual a autora editou 25 documentos - relacionados à temática indígena, extraídos do Arquivo Histórico Ultramarino (AHU) -, sob a orientação de Américo Venâncio Lopes Machado Filho e co-orientação de Zenaide de Oliveira Novais Carneiro.

${ }^{3}$ Destaques nossos.
} 
Esse tipo de requerimento - embora raro - não parece constituir um caso isolado, uma vez que é corrente, na historiografia, a citação de documentos concernentes a pedidos, os mais diversos, dos indígenas, conforme se pode observar, a título de ilustração, no Anexo 1, extraído de Carneiro (2013), o qual aponta caminhos distintos para a compilação de fontes indiretas - quiçá diretas -, as quais, ainda que extremamente fragmentadas, não podem passar ao largo, haja vista serem os indígenas atores na cena de constituição do chamado português geral brasileiro, antecedente histórico do português popular brasileiro ${ }^{4}$, cujo estudo só é possível por meio de indícios. Essa vertente popular "fez-se e faz-se, ainda, não tanto quanto antes, é claro, na oralidade, no encontro multilinguístico da população indígena autóctone, do português europeu do colonizador, da população de origem africana que aqui começou a chegar na década de 30 do século XVI", como defende Mattos e Silva (2008, p. 23). A autora propõe

que a busca de seu percurso histórico tem de ser feita não fundada em corpora escritos, organizáveis $a d$ hoc, como para o português culto brasileiro, como é óbvio, mas num processo de reconstrução do tipo - que designarei metaforicamente - arqueológico, em que, de evidências dispersas, calçadas pelas teorias sobre o contacto lingüístico e pela história social do Brasil, se possa chegar a formulações convincentes. Percuso análogo, mutatis mutandis e modus in rebus, ao da reconstrução do chamado "latim vulgar", cuja principal fonte de estudo é o seu resultado, as línguas românicas (op. cit., p. 24) .

A documentação originada no âmbito da implantação do Diretório Pombalino, no que concerne à criação de vilas, a partir de aldeamentos jesuítas, pode trazer a lume alguns outros documentos do Brasil colonial, tendo em vista o fato de os indígenas e conquistadores terem travado batalhas, as mais diversas, criando elementos de conexão cultural ${ }^{6}$.

$\mathrm{Na}$ sequência, apresentamos evidências de indígenas alfabetizados no litoral baiano, no século XVIII - objetivo primordial deste trabalho - e apontamos caminhos para o

\footnotetext{
${ }^{4} \mathrm{~A}$ acepção "português popular" é considerada, tendo como base a pressuposição de que o português brasileiro apresenta origens históricas distintas, uma vertente popular e uma vertente culta, conforme defende Mattos e Silva (2001 e 2002, entre outros). Essa visão está de acordo com a proposta de Lucchesi (1994, 2001), que concebe o português brasileiro como um sistema não apenas heterogêneo e variável, mas plural; um diassistema, formado por dois subsistemas, por sua vez, igualmente heterogêneos e variáveis, configurando esses dois macrossistemas uma polarização linguística, a partir do que propõe Silva Neto (1986 [1950]: 234-235). Lucchesi diverge, todavia, fortemente de Silva Neto, quanto à questão da unidade e conservadorismo e à visão de uma suposta hierarquia de culturas. Atualmente, as diferenças entre essas vertentes já não são tão perceptíveis na fala, o que revela uma aproximação entre elas, conforme demonstrou Lucchesi (1994).

${ }^{5}$ Cf. Carneiro et al, sobre o Português geral brasileiro nos sertões baianos seiscentistas: em busca de indícios sobre a participação indigena (no prelo).

${ }^{6}$ Carneiro (2013) aponta ser a busca nos acervos do AHU um dos caminhos para chegar a esses outros documentos, ao lado de pesquisas em acervos diversos, tais como os acervos do Arquivo Romano da Companhia de Jesus (A.R.S.I.) - bem analisados por Pompa (2011) - e os acervos do chamado "Armário Jesuítico", do Arquivo da Casa da Coroa, da Torre do Tombo, onde constam documentos da Companhia de Jesus e suas missões na Bahia.
} 
estudo da inserção do indígena na escrita portuguesa, nos sertões baianos.

\section{INDÍGENAS ALFABETIZADOS NA AMÉRICA ESPANHOLA, NO MUNDO COLONIAL BRASILEIRO NÃO- PORTUGUÊS E NO ÂMBITO DA COLONIZAÇÃO PORTUGUESA}

Nesta seção, está descrito, em breves linhas, como se deu a inserção da escrita no universo indígena espanhol e no universo indígena brasileiro, motivada, embora em moldes diferentes, pelas práticas de evangelização.

\subsection{A AMÉRICA ESPANHOLA E A INSERÇÃO DE ALDEADOS NA CULTURA ESCRITA}

Neumann (2005, p. 178) - em sua tese intitulada Práticas letradas Guarani: produção e usos da escrita indígena (séculos XVII-XVIII) - refere-se a uma intensa troca de bilhetes, cartas e avisos entre os Guarani das Missões, em meados do século XVIII; cita o jesuíta Thadeo Xavier Henis, autor do diário Mientras volaban correos por los pueblos, e o caso do cacique da redução de Santa Maria La Mayor, Nicolas Yapuguai, que, em 1727, recriou, em língua guarani, o livro Sermones y Ejemplos em Lengua Guarani.

De acordo com Neumann, na América de colonização espanhola, as populações indígenas - principalmente seus representantes letrados - adotaram, a partir de meados do século XVI, a redação de cartas como instrumento de contato com o "mundo exterior”. A redação dessas cartas poderia variar quanto aos conteúdos, à forma e aos idiomas em que eram grafadas. Refere-se o autor a uma dessas missivas indígenas, redigida no logradouro de Santo Antônio - um posto dentro da extensa estância de São Miguel , poucos dias depois do primeiro encontro dos índios miguelistas com os comissários demarcadores, em Santa Tecla, para aprenderem a prática de escrita entre os índios Guarani ${ }^{7}$.

A instrução letrada, para Neumann (2004, 2005, 2009, 2015, 2016), é indissociável da catequese promovida nas reduções, que proporcionou aos índios missioneiros as condições para produzirem novas formas de expressão. Por meio das atividades religiosas e administrativas, os Guarani conviveram com as práticas letradas, que produziram efeitos sobre toda coletividade (cf. anexo 4). A alfabetização nas reduções esteve limitada aos índios mais aptos ou àqueles de maior confiança dos missionários, ou seja, os que integravam a "elite missionária".

Neumann (2005, p. 48-59) se propõe a analisar aspectos relacionados à escrita como uma prática sociocultural, demonstrando em que circunstâncias os Guarani fizeram uso da habilidade gráfica ou recorreram à aptidão de outros para produzirem relatos. $\mathrm{O}$ autor faz uma detalhada análise desse tema e mostra como os contextos socioculturais, no

\footnotetext{
${ }^{7} \mathrm{O}$ autor chama a atenção para o fato de que, em outras partes da América, antes do domínio português, índios principais do México escreveram ao príncipe Felipe da Espanha uma demanda, pleiteando o direito de autogoverno, denunciando as dificuldades que estavam enfrentando.
} 
processo de evangelização, gestaram a prática da escrita, que culminou em uma produção escrita Guarani, nos séculos XVII e XVIII, descrevendo não só o uso de suportes de escrita - o papel dos copistas -, como também especificando a sua produção textual (cartas, memórias, atas de cabildos, diários, narrativas históricas, entre outros tipos).

A análise dos contextos socioculturais inicia-se com o processo de evangelização, calcado na prática primária (oral), que norteou a primeira geração de Guarani aldeados; depois se volta para os meandros da convivência Guarani com a cultura da escrita, também em língua nativa, além do espanhol, gerando uma situação, ainda que controlada pelos jesuítas, de bilinguismo. A evangelização pautada na oralidade coexistiu com a prática da escrita nas reduções.

O autor mostra, ainda, que essa prática de escrita foi também controlada, restrita aos homens; dentre esses, quase que exclusivamente, as chamadas lideranças indígenas. Essa "elite letrada" teve um papel tanto no processo de evangelização, quanto na administração das reduções; destaca-se o papel do cabildo, constituído basicamente por índios principais; ao secretário do cabildo cabia, por exemplo, a redação de acordos e despachos. Para além dos líderes, conviviam com a escrita outros indígenas, segundo Neumann, envolvidos nas congregações e nominas, que remetiam às potencialidades inerentes ao contato com a escrita.

Os usos variados de escrita nas reduções - mesmo que praticamente restritos a essa "elite indígena letrada missionária" - promoviam, na concepção do autor, novos modos de relação no processo de evangelização, gerando oportunidades de essa elite letrada colocar em prática o saber letrado, em outros contextos, para além do espaço das reduções.

Em suma, Neumann defende que o conhecimento das regras epistolares permitiu aos índios estabelecer canais de comunicação diretamente com a administração colonial, por meio do envio de cartas e memoriais, em que procuravam atuar dentro do legalismo das regras escritas.

\subsection{AS CARTAS DOS CHEFES POTIGUARA PEDRO POTI E ANTONIO PARAUPABA (SÉCULO XVII)}

No Brasil, as notícias mais conhecidas das cartas dos chefes Potiguara Pedro Poti e Antonio Paraupaba são as dadas por José Hygino Duarte Pereira, em fins do século XIX, no Arquivo da Companhia das Índias Ocidentais, em Haia. Hulsman (2006) refere-se às cartas atribuídas ao indígena Potiguar Antônio Paraupaba e o define como um escritor experiente; suas petições, segundo o autor, são testemunhos da relação entre os índios e os neerlandeses, durante 32 anos. Para ele, esses textos - se não escritos - foram lidos e corrigidos por Paraupaba, publicados originalmente em Leiden, na Holanda, em 1657. O primeiro foi registrado em agosto de 1654, e o segundo é uma versão manuscrita, datada de abril de 1656, ainda preservada. O autor faz também referências a textos da autoria de Paraupaba nas "Minutas Diárias do Alto Conselho da Companhia das Índias Ocidentais no Recife". De acordo com Gonçalves (2005), esses escritos das Minutas foram produzidos durante o mês de outubro de 1645 , em plena guerra luso-holandesa, no 
intenso movimento ocorrido com as tropas Potiguara; mensageiros iam e voltavam dos acampamentos militares, situados entre Pernambuco e Paraíba, portando cartas.

As cartas de Paraupaba e as respostas de Pedro Poti às cartas de Dom Antônio Felipe Camarão comprovam a existência de indígenas alfabetizados no Brasil do Século XVII. Cabe ressaltar que, a nosso ver - ainda que não escritos em português -, esses documentos são importantes testemunhos da "inserção dos índios no mundo colonial", como defende Pompa (2004, p. 209-210), que chama a atenção para a comunicação feita por meio de cartas, como testemunhado por Vieira, na Relação da Missão da Serra de Ibiapaba, de 1650 (VIEIRA, 1992). Vieira (1992, p. 139-140) refere-se a cartas enviadas por vários grupos indígenas e faz observações sobre a letra, o estilo e a identidade dos remetentes: "admiraram-se os padres de ver as cartas escritas em papel Veneza e fechadas com lacre da Índia (...). A letra e o estilo das cartas era dos índios pernambucanos, antigos discípulos dos padres...”.

\subsection{ALUSÕES A SOLICITAÇÕES DE INDÍGENAS NO ÂMBITO DO DOMÍNIO PORTUGUÊS NO BRASIL}

$\mathrm{Na}$ historiografia, existem referências a diversas solicitações de indígenas, em pareceres enviados ao Conselho Ultramarino; não está claro, todavia, se tais escritos têm uma autoria indígena. Carvalho Jr. (2005) cita pedidos de dois índios principais de Tapuitapera e Sergipe - que prestaram serviços na guerra contra os holandeses -, feitos em 12 de setembro de $1648^{8}$; solicitam a mercê do Hábito de Cristo e sua terça correspondente, para poderem viver. Segundo o autor, os pedidos se multiplicaram, sobretudo em 1655.

Almeida (2001, p. 56) esclarece que, nas petições ao Rei, os indígenas se identificavam com o nome de batismo português, com o nome da aldeia, e não com o nome do grupo étnico a que pertenciam. Ressalta a autora que esses indígenas "eram súditos do Rei, com reconhecimento jurídico sobre sua condição específica de aldeados"; dá o exemplo da aldeia de São Lourenço e dos índios Temiminó. Os índios aldeados, de acordo com Almeida, apareciam ainda, no século XIX, como "agentes sociais mais interessados, senão únicos, em manter suas aldeias".

Os aldeamentos foram bastante comuns nos sertões baianos, tendo, posteriormente, muitos, sido transformados em vilas, sobretudo após a expulsão dos jesuítas, em 1759 (cf. seção 4). Diversas vilas no sertão foram originárias de antigos aldeamentos, a exemplo de Jeremoabo, Bom Conselho (Cícero Dantas), Santa Tereza de Canabrava, Pombal (Ribeira do Pombal), aldeia de Tupinambás (Soure), Tucano, Saco dos Morcegos/Mirandela, aldeia de índios Moritis e Cariris (Ribeira do Pombal), Maçacará (Euclides da Cunha) e outra vila da Região Norte, como Pambu, Santo Antônio da Glória, nos século XVII e XVIII ${ }^{9}$. E outros indígenas se agruparam e, ainda hoje, remanescentes

${ }^{8}$ AHU, Maranhão, 009, cx 3. d. 266 e 268.

${ }^{9}$ Cf. dados de MATTOSO, Kátia M. Queirós de. (1992). Babia, Século XIX: uma província no Império. Rio de Janeiro: Editora Nova Fronteira, e de VILHENA, Luís dos Santos (1969). A Babia no século XVIII. Salvador: Editora Itapuã - Coleção baiana, vol. 1 e vol. 2. 
vivem, na região, a despeito dos problemas de demarcação territorial, como os Tumbalalá, Truká, Tuxá, Kantaruré, Xukuru-Kariri, Pankaré, Tocas, Kaimbé, Kiriri, Aricobé, Atikúm e Pankaru. Não é impossível que se encontrem evidências de indígenas alfabetizados nesses aldeamentos e que, eventualmente, possam ter feito uso da escrita, para exigência de cumprimento de algum propósito, como fizeram os ex-aldeados na Vila de Abrantes, da qual falaremos a seguir ${ }^{10}$.

\section{LITORAL BAIANO SETECENTISTA: INDÍGENAS ALFABETIZADOS ATUANDO NA ADMINISTRAÇÃO DA VILA DE ABRANTES}

O Juiz de Fora da Cidade de Salvador, João Ferreira Bittencourt e Sá, designado para realizar a transição do Aldeamento do Espírito Santo de Ipitanga (a aldeia de Ipitanga) - fundada em 1558, sob o Orago do Espírito Santo, tendo sido um dos primeiros aldeamentos dos Jesuítas (Leite, 1938-1950, p. 53) - à Vila de Abrantes, no dia 18 de setembro de 1758, fez inúmeras diligências aos membros do Tribunal Especial do Conselho Ultramarino, em Salvador, produzindo vasta documentação sobre esse processo. Para Santos (2002), os ministros foram instruídos para deslocarem-se às aldeias e proceder às seguintes ações: intimar os religiosos a deixar as vilas, assim que chegassem os novos párocos; publicar e explicitar aos índios as novas leis, a condição de elevação da aldeia à vila; erguer o pelourinho na praça, supervisionar as eleições para vereadores, juízes ordinários e outras atribuições.

Brunet (2008) analisa - no seu interessante trabalho, intitulado De aldeados a súditos: viver, trabalhar e resistir em Nova Abrantes do Espirito Santo - Babia, 1758-1760 - a primeira petição ao Conselho Ultramarino, datada de 09/12/1758, de autoria dos Índios da Vila de Abrantes (APEB, Maço 603, Caderno 1), e afirma que, entre os 67 casais registrados no censo do aldeamento do Espírito Santo, durante a fundação da Vila de Abrantes, poucos sabiam ler e escrever, apesar de a maioria entender e falar português; apresenta o autor uma lista dos indígenas que sabiam ler e escrever e que vieram a assumir cargos na administração da nova vila criada a partir do aldeamento do Espírito Santo.

Afirma Santos (2002, p. 95) que o Juiz de Fora teve grande dificuldade em encontrar, entre os 236 índios (sendo 123 mulheres) da Vila de Abrantes, quem estivesse apto para participar da eleição e preencher os cargos civis criados, haja vista o número reduzido de alfabetizados, que pode dever-se ao desinteresse dos jesuítas em se ocupar do ensino ou ao descaso inicial dos indígenas em se submeter ao regime escolar imposto pelos jesuítas. Além do mais, conforme ressalta Santos, "o conteúdo programático e o calendário escolar dos inacianos não se ajustavam aos interesses e ao ciclo de atividades produtivas dos aldeados".

Brunet (2008, p. 91) mostra que, na implantação da Vila de Abrantes, houve, pelo menos temporariamente, o intento de que indígenas alfabetizados e próximos aos

\footnotetext{
${ }^{10} \mathrm{O}$ levantamento de fontes dessa natureza passou também a ser feito por Pedro Daniel dos Santos Souza, na tese, em andamento, intitulada "De todos que sabiam ler e escrever": a reconstrução das histórias de penetração das populações indígenas brasileiras no mundo da cultura escrita, iniciada em 2015, na Universidade Federal da Bahia. Cf. também Souza; Lobo (2016).
} 
portugueses assumissem cargos:

de juiz ordinário, que também atuaria como juiz de órfãos, vereadores, procurador do conselho, escrivão da câmara, que acumularia o cargo com o de tabelião de notas e o de escrivão judicial e dos órfãos, e o de alcaide e seu escrivão, além de um porteiro público e outro para a câmara, cujos mandatos eram interinos, dentre os mais capazes. Bittencourt e Sá deveria, ainda, dar juramento e posse aos novos eleitos, escolher as casas que considerasse mais decentes para as reuniões da câmara e as audiências do juiz e para a cadeia pública, além de determinar os dias de reunião da câmara.

O levantamento - feito em Carneiro (2008, 2011, 2013) - nos documentos do Maço 603, Caderno 11, mostra a situação de indígenas da Vila de Abrantes que liam e escreviam "muito mal", conforme Bittencourt e Sá, o qual fez uma lista com os cargos que eles ocupavam. Esses indígenas aparecem assumindo funções na vila recém-criada, lavradas pelo tabelião Bernardino Sena", segundo o qual "todos eram filhos de Europeus e creados na Cidade". Brunet (2008, p. 92) afirma "que foram criados em Salvador e retornaram ao local de nascimento, onde se casaram com índias e aí passaram a viver" e que, na qualidade de "mistos" - como eram chamados então os mestiços -, sendo educados fora do aldeamento, falantes do português e dominando a escrita, foram considerados, pelo Juiz de Fora, como os mais aptos para atuarem na nova administração.

A seguir, um Quadro, adaptado de Carneiro (2013), com os nomes dos indígenas que atuavam na administração da nova Vila e sua relação com a leitura e a escrita:

\begin{tabular}{|c|c|c|c|c|c|}
\hline $\begin{array}{ll}\text { Nome } & \text { dos } \\
\text { indígenas }\end{array}$ & Ocupação & $\begin{array}{l}\text { Lề } \\
\text { (suficientemente) }\end{array}$ & $\begin{array}{l}\text { Escreve } \\
\text { mal }\end{array}$ & $\begin{array}{l}\text { Não } \\
\text { Escreve }\end{array}$ & $\begin{array}{l}\text { Não } \\
\text { Declarada }\end{array}$ \\
\hline Pedro dos Reis & $\begin{array}{l}\text { Juiz Ordinário } \\
\text { (posteriormente } \\
\text { nomeado Capitão-mor } \\
\text { das Ordenanças da } \\
\text { vila até a sua morte, por } \\
\text { volta de 1789) }\end{array}$ & Sim & Sim & & \\
\hline Jerônimo Xavier & Escrivão de Alcaide $^{12}$ & Sim & $\operatorname{Sim}$ & & \\
\hline Francisco Xavier & $\begin{array}{l}\text { Escrivão da Vara de } \\
\text { Alcaide }\end{array}$ & Sim & Sim & & \\
\hline Francisco Lopes & Vereador & Sim & Sim & & \\
\hline Antonio Borges & Vereador & & & & - \\
\hline $\begin{array}{l}\text { Apolinário } \\
\text { Fernandes }\end{array}$ & Vereador & & & & - \\
\hline $\begin{array}{ll}\text { Jerônimo } & \text { de } \\
\text { Albuquerque } & \end{array}$ & Procurador da Câmara & & & & - \\
\hline
\end{tabular}

11 APEB. Maço 603. Seção Colonial - Índios, Cadernos 27, 30 e 31 de 1758.

12 Jerônimo Xavier foi substituído em 23 de fevereiro de 1959 pelo colono Francisco de Lima Pinto, para tabelião de notas e escrivão, sob a alegação de que não tinha capacidade para escrever. De acordo com Brunet (2008, p. 93), "os outros índios, eleitos anteriormente, foram mantidos em seus cargos, com mandatos de dois anos, quando se realizaria nova eleição"; registre-se que o interino juiz ordinário da câmara era o índio Pedro dos Reis, responsável pela guarda das cédulas de votação. 


\begin{tabular}{|l|l|l|l|l|l|}
\hline Jerônimo Peres & $\begin{array}{l}\text { Porteiro Porteiro } \\
\text { Homem de Vara } \\
\text { "por não escrever, mas } \\
\text { apenas ler" }\end{array}$ & Sim & Sim & \\
\hline Total: 08 & & & & & \\
\hline
\end{tabular}

Quadro 1 - Nome dos ocupantes dos cargos e sua relação com a leitura e a escrita Fonte: adaptado de Carneiro (2013).

Parte desses indígenas aparece assinando, em junho de 1759, uma petição apresentada por Brunet (2008, p. 105) -, originada da Vila de Abrantes, reivindicando as terras da Capivara. As assinaturas são de Pedro dos Reis, Francisco Lopes, Antonio Borges, Apolinário Fernandes e Jerônimo de Albuquerque (cf. Figura 1):

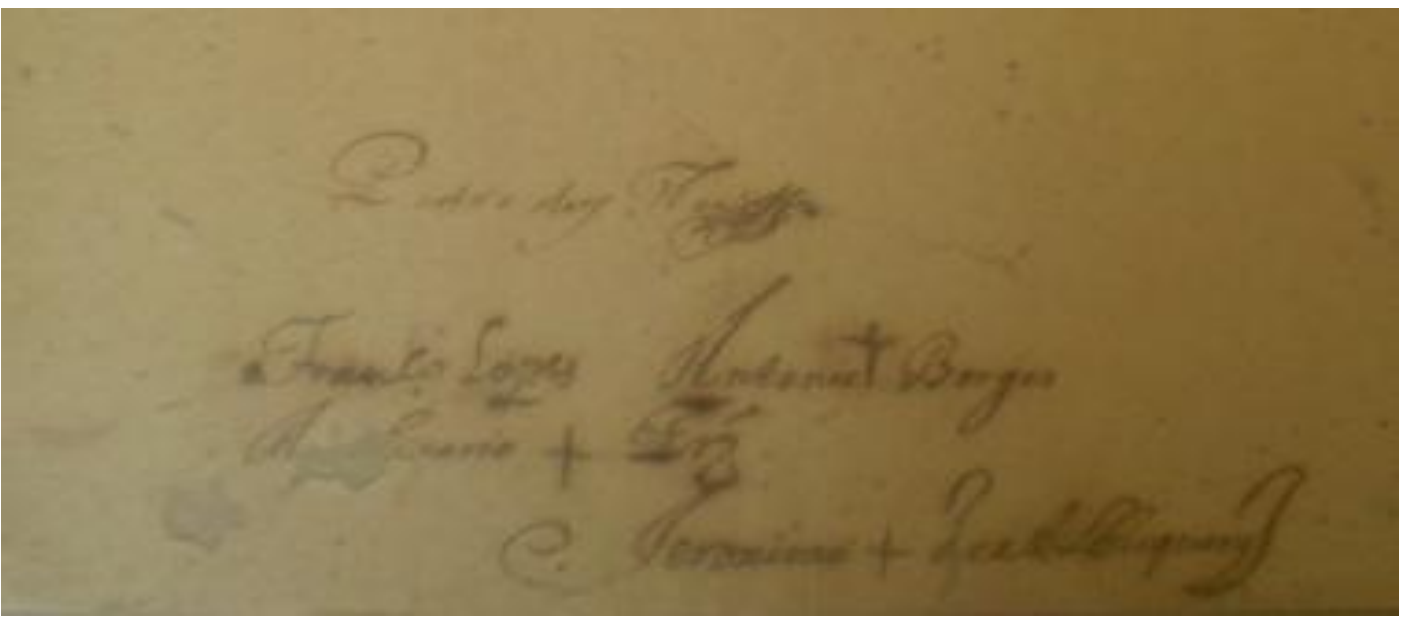

Figura 1 - Assinatura de indígenas que assumiram cargos na Vila de Abrantes, na petição reivindicando as Terras da Capivara

Fonte: Excerto do Maço 603, Cad. 28, do APEB, datado de junho de 1759 (Extraído de Carneiro, 2013).

\section{EM BUSCA DE FONTES PRODUZIDAS POR INDÍGENAS ALFABETIZADOS EM ALDEAMENTOS NO SEMIÁRIDO BAIANO: PARA O ESTUDO DO PORTUGUÊS POPULAR BRASILEIRO}

As pesquisas desenvolvidas por Santos (1988; 2002; 2012; 2016), Carvalho Jr. (2005), Silva Jr. (2007), Siering (2008), Brunet (2008), entre outros, trazem informações importantes que nos levam a entender o complexo ambiente de relações entre indígenas, missionários e colonizadores, a partir do século XVI, e as linhas essenciais na construção das dicotomias sertão/Tapuias/Macro-Jê e costa/Tupinambá/Macro-Tupi. É importante destacar o encontro entre Tapuia e missionários na construção do espaço do "aldeamento", com as implicações linguísticas daí advindas, desde o contato de línguas até a inserção do indígena no mundo da escrita. Os aldeamentos coloniais constituídos sob a proteção da Coroa Portuguesa, ao longo de mais de dois séculos, por diversas ordens religiosas, devem ser pensados, segundo Almeida (2001, p. 52) - cf. Anexo 4 -, como 
espaços em que "várias gerações de índios se transformaram de etnias múltiplas num amplo e genérico grupo que chamamos de índios aldeados".

Como está fartamente documentado na historiografia, diversas vilas sertanejas da Bahia foram antigos aldeamentos, ${ }^{13}$ como as referidas Vilas de Jeremoabo, Bom Conselho (Cícero Dantas), Santa Tereza de Canabrava, (Ribeira do Pombal), Soure, Tucano, Saco dos Morcegos/Mirandela, Ribeira do Pombal, Maçacará (Euclides da Cunha), nos século XVII e XVIII.

A busca nos arquivos talvez possa revelar, nas vilas de Soure, Mirandela e Pombal, nos sertões baianos, situações próximas à encontrada na Vila de Abrantes.

\begin{tabular}{|l|l|l|l|l|}
\hline Aldeia & Localização & Vilas & Ministro & Função \\
\hline Ipitanga & Bahia & Abrantes & $\begin{array}{l}\text { João Ferreira de } \\
\text { Bitencourt e Sá }\end{array}$ & Juiz de fora da cidade da Bahia \\
\hline Natuba & Bahia & Soure & Luiz Freire de Veras & Juiz de Fora da Vila da Cachoeira \\
\hline $\begin{array}{l}\text { Saco dos } \\
\text { Morcegos }\end{array}$ & Bahia & Mirandela & $\begin{array}{l}\text { Miguel de Arez Lobo } \\
\text { de Carvalho }\end{array}$ & $\begin{array}{l}\text { Ouvidor e corregedor da Comarca de } \\
\text { Sergipe d'El Rei }\end{array}$ \\
\hline Canabrava & Bahia & Pombal & $\begin{array}{l}\text { Miguel de Arez Lobo } \\
\text { de Carvalho }\end{array}$ & $\begin{array}{l}\text { Ouvidor e corregedor da Comarca de } \\
\text { Sergipe d'El Rei }\end{array}$ \\
\hline
\end{tabular}

Quadro 2 - Lista de vilas da região semiárida e dos ministros responsáveis por sua criação

Fonte: AHU/BA, Avulsos, cx. 139, doc. 10701. Cf. informações mais detalhadas no Anexo. AHU/BA, Avulsos, cx. 139, doc. 10701, n. 5 e 6. Sobre a fundação e a trajetória histórica da aldeia em questão cf. LEITE, 1938-1950, t. II, p 53; BRUNET, 2008; MAGALHÃES, 2010, APEB, seção Colonial e Provincial, maço 603, cad. 11. AHU/BA, Avulsos, cx. 139, doc. 10701 (Adaptado de Santos, 2002, p. 112-113).

Haveria fontes produzidas por indígenas escolarizados no período colonial brasileiro, a partir do século XVII, na região do semiárido, nos sertões da Bahia, na área do Rio São Francisco e das Jacobinas e em áreas vizinhas? Pompa (2001, 2003), entre outros, traz uma descrição detalhada da situação da região no século XVII, cujas aldeias parecem ter sido organizadas segundo o modelo do litoral, como a Vila de Abrantes, por exemplo.

\footnotetext{
${ }^{13}$ Spix e Martius (1916) descrevem um desses lugares “... para visitar os índios da Vila da Pedra Branca, légua e meia a S. S. O. de Tapera, onde havíamos armado o nosso pouso. O dono dessa fazenda acompanhou-nos até lá, por um caminho estreito, entre outeiros cobertos de mato. Encontramos filas de palhoças baixas, de taipa, e, no meio delas, uma igreja da mesma construção, distinguindo-se sòmente [sic] por um altar pobremente ornamentado. Defronte desse templo, avistamos grande parte dos índios e uns poucos colonos de outras raças, reunidos para ouvir missa. Os silvícolas, que vivem aqui há uns trinta anos, reunidos sob a direção de um juiz brasileiro e de um escrivão, pertencem às tribos dos cariris e dos sabujás. Moram os primeiros na própria Vila da Pedra Branca; os outros, num povoado, chamado Caranguejo, distante meia hora mais ao sul. Antes de se estabelecerem sob o domínio brasileiro, eles viviam dispersos nas matas dos montes vizinhos. Atualmente formam um distrito de umas 600 almas. Ambas estas tribos entretêm relações de recíproca boa harmonia, e não se distinguem uma da outra, nem pela conformação do corpo, nem pelos costumes e hábitos, mas apenas pela diferença das línguas. São de estatura mediana, bastante esbelta, de compleição nada forte, de côr [sic] pardo-clara...” (p. 145)
} 
A fim de servir como guia para futuras pesquisas, Carneiro (2013) fez um levantamento prévio dos aldeamentos baianos na área do semiárido (conforme Quadro 3); o rastreamento de sua documentação pode conduzir a uma via semelhante à encontrada em Abrantes, além de esclarecer sobre seu modus operandi ${ }^{14}$, no que tange, especificamente, ao ensino da língua portuguesa, bem como às políticas linguísticas daí advindas.

Os primeiros aldeamentos foram iniciados às margens do Rio São Francisco, já em 1551 (Nóbrega), com a administração de aldeias, a partir de 1595, não havendo um levantamento preciso sobre a quantidade de aldeamentos, devido aos seus frequentes deslocamentos, sobretudo no período das chamadas Guerras dos Bárbaros, também em razão de secas.

No Quadro 3, abaixo, apresentamos os aldeamentos na área do semiárido, nos séculos XVII-XVIII:

\begin{tabular}{|c|c|c|c|}
\hline $\begin{array}{l}\text { Aldeias/ } \\
\text { Denominações }\end{array}$ & $\begin{array}{l}\text { Invocação } \\
\text { ou Orago }\end{array}$ & Missionários & $\begin{array}{l}\text { Nação/ } \\
\text { habitantes }\end{array}$ \\
\hline $\begin{array}{l}\text { 1. Aracapá [Uracapá, Ouracapa } \\
\text { Oacarapá Wracapa, Racappa, Varacapá] } \\
\text { Ilha do Orocapâ } \\
\text { Ilha do Aracapá }\end{array}$ & São Francisco & $\begin{array}{l}\text { Capuchinhos } \\
\text { bretões/franceses/ } \\
\text { Carmelitas Descalços } \\
\text { Capuchinhos } \\
\text { Italianos }\end{array}$ & $\begin{array}{l}\text { Cariri- dzubucuás } \\
\text { Obacatuaras/ } \\
\text { [Obacaiaras/Abacatuaras] } \\
\text { Irapuás/Cracuís }\end{array}$ \\
\hline Aramaris & - & Clérigos & Kiriri \\
\hline Aramurus & & Capuchinhos & $\begin{array}{l}\text { Aramurus } \\
\text { Caboclos (Xocós [chocó, chocázr, } \\
\text { ceocoses, schocón) }\end{array}$ \\
\hline Aranhipó & & $\begin{array}{l}\text { Jesuitas } \\
\text { Carmelitas Descalços }\end{array}$ & Pórcáz \\
\hline Araripe [Arrarype] & $\begin{array}{ll}\text { Senhor } & \text { Santo } \\
\text { Cristo } & \end{array}$ & $\begin{array}{l}\text { Capuchinhos } \\
\text { franceses } \\
\text { Capuchinhos italianos }\end{array}$ & $\begin{array}{l}\text { Umãs } \\
\text { Ansuns } \\
\text { Enxus }\end{array}$ \\
\hline Aricobé & $\begin{array}{l}\text { Nossa Senhora da } \\
\text { Conceição }\end{array}$ & & \\
\hline
\end{tabular}

${ }^{14}$ Sobre o direcionamento desses espaços, cf. Castelnau-l'Estoile (2006).

15 Muitas aldeias passaram dos jesuítas para os capuchinhos e vice-versa. Pompa (2003, p. 304-305) identifica, sob domínio dos capuchinhos, em fins do século XVII, as aldeias de Arará, Vargem, Pambu, Aracapá, Cavalo, Arapuá (Irapuã), Rodelas (Comarca de Jacobina, Porto da Folha (Sergipe), Pacatuba (Sergipe) e Rio de Contas. E, na área do curso inferior do rio São Francisco, entre 1670 e 1700, das ordens capuchinhas, jesuíticas e franciscanas, as seguintes missões: Pochim/Pacatuba, Vila Nova de Penedo, Vila de Traipu ou São Pedro do Porto da Folha, Paulo Afonso, Rodela, Sorobabé, Porto das Missões dos Rodelas, Ilha e Porto da Missão, Vargem, Pambu, Ilha das Vacas, Aracapá, Cavalo-São Felix, Ilha dos Guanhãs, Joaseiro, Curral dos Bois e Carurus. Ainda hoje, remanescentes vivem na região, a despeito dos problemas de demarcação territorial, a saber: os Tumbalalá, Truká, Tuxá, Kantaruré, Xukuru-Kariri, Pankaré, Tocas, Kaimbé, Kiriri, Aricobé, Atikúm e Pankaru. A população, no entanto, é pequena, variando de 50 indíviduos - a exemplo dos Kiriri das terras do Rodeador, em Cícero Dantas, e os Atikúm do Angical - até, no máximo, 1.350 entre os Kiriri do Banzaê (cf. http://www.pineb.ffch.ufba.br; http://www.sei.ba.gov.br e www.unb.br/il/lali). 


\begin{tabular}{|c|c|c|c|}
\hline $\begin{array}{l}\text { 7. Axará [Acará, Acaxá] } \\
\text { Ilha do Araxá } \\
\text { Illha do Acará }\end{array}$ & $\begin{array}{l}\text { Nossa Senhora de } \\
\text { Belém }\end{array}$ & $\begin{array}{l}\text { Capuchinhos } \\
\text { franceses } \\
\text { Jesuítas } \\
\text { Carmelitas Descalços } \\
\text { Capuchinhos } \\
\text { Italianos }\end{array}$ & $\begin{array}{ll}\text { Procás [Porcáz, } & \text { Porcás, ]e } \\
\text { Brancarurus } & \text { [pancarurus, } \\
\text { bancarurus] } & \\
\text { (Tapuia) } & \end{array}$ \\
\hline Boldrim (Taipu) & $\begin{array}{l}\text { Nossa Senhora do } \\
\text { Pilar }\end{array}$ & $\begin{array}{l}\text { Capuchinhos } \\
\text { franceses } \\
\text { Capuchinhos italianos }\end{array}$ & Cariris \\
\hline Bom Jesus de Jacobina/ Jacobina & $\begin{array}{l}\text { Bom Jesus da } \\
\text { Glória }\end{array}$ & Franciscanos & Paracá \\
\hline Camamu & $\begin{array}{l}\text { Nossa Senhora do } \\
\text { Desterro }\end{array}$ & Franciscanos & Cariri \\
\hline $\begin{array}{lll}11 . \quad \text { Canabrava/Santa Tereza de } \\
\text { Canabrava }\end{array}$ & Santa Tereza & Jesuítas & Kiriri/Cariri \\
\hline 12. $\quad$ Caranguejo & - & - & Sapuyá \\
\hline Caruruz & & Jesuítas & \\
\hline 14. $\quad$ Catu & Santo Antônio & Franciscanos & Cariri \\
\hline $\begin{array}{l}\text { 15. Cavalo/São Félix } \\
\text { Ilha do Cavalo }\end{array}$ & $\begin{array}{l}\text { São Felix } \\
\text { Nossa Senhora da } \\
\text { Natividade }\end{array}$ & $\begin{array}{l}\text { Capuchinhos } \\
\text { franceses } \\
\text { Carmelitas Descalços } \\
\text { Capuchinhos } \\
\text { Italianos }\end{array}$ & Cariri \\
\hline Conquista da Pedra Branca & - & - & Kiriri/Cariri \\
\hline Conquista de Pedra Branca & & & Kariri \\
\hline Coripós & $\begin{array}{l}\text { Nossa Senhora do } \\
\text { Pilar }\end{array}$ & & \\
\hline Corumambá [Corumbambá] & São João & $\begin{array}{l}\text { Capuchinhos } \\
\text { franceses } \\
\text { Jesuítas } \\
\text { Carmelitas Descalços }\end{array}$ & Porcáz \\
\hline Curral de Bois e Carurus & $\begin{array}{l}\text { São Francisco } \\
\text { Santo Antônio }\end{array}$ & $\begin{array}{l}\text { Jesuítas } \\
\text { Franciscanos }\end{array}$ & Guaimoré \\
\hline Gualaz & & Franciscanos & \\
\hline Ilha das Vacas & & Capuchinhos & \\
\hline Ilha do Jacaré & São Pedro & $\begin{array}{l}\text { Capuchinhos } \\
\text { franceses } \\
\text { Carmelitas Descalços }\end{array}$ & Aramurus \\
\hline Ilha dos Guanhãs & & Franciscanos & \\
\hline Ilha e Porto das Missões & & Capuchinhos & \\
\hline $26 . \quad$ Ipitanga & Espírito Santo & Jesuítas & Tupi ou Tupinambá \\
\hline $\begin{array}{l}27 . \quad \text { Irapuã [Irapoá, Arapuá] } \\
\text { Ilha do Irapoa }\end{array}$ & $\begin{array}{l}\text { Santo Antônio } \\
\text { São Felix de } \\
\text { Cantalício }\end{array}$ & $\begin{array}{l}\text { Capuchinhos } \\
\text { franceses } \\
\text { Carmelitas Descalços } \\
\text { Capuchinhos } \\
\text { Italianos }\end{array}$ & $\begin{array}{l}\text { Cariri } \\
\text { Cracuis } \\
\text { Ansus }\end{array}$ \\
\hline Itapicuru de Cima & $\begin{array}{l}\text { Santo Antonio } \\
\text { Nossa Senhora da } \\
\text { Saúde }\end{array}$ & Franciscanos & $\begin{array}{l}\text { Payayá (?) } \\
\text { Tupinambá }\end{array}$ \\
\hline 29. Jaguaripe do Rio da Aldeia & Santo Antônio & Clérigos & Kiriri/Cariri \\
\hline $\begin{array}{l}30 . \quad \text { Jeremoabo/ } \\
\text { Geremoabo }\end{array}$ & $\begin{array}{l}\text { Nossa Senhora das } \\
\text { Brotas }\end{array}$ & Franciscanos & Tupinambá \\
\hline 31. Jeru & $\begin{array}{l}\text { Nossa Senhora do } \\
\text { Socorro }\end{array}$ & Jesuítas & \\
\hline Jiquirica & $\begin{array}{l}\text { Nossa Senhora dos } \\
\text { Prazeres }\end{array}$ & Clérigos & - \\
\hline Juazeiro & $\begin{array}{l}\text { Nossa Senhora das } \\
\text { Brotas/ Nossa } \\
\text { Senhora das Grotas }\end{array}$ & Franciscanos & Tamanqueri \\
\hline Manguinhos & - & Clérigo/ Jesuítas & (Caramuru) \\
\hline Massacará & $\begin{array}{l}\text { Santíssima } \\
\text { Trindade }\end{array}$ & $\begin{array}{l}\text { Franciscanos } \\
\text { Jesuítas }\end{array}$ & $\begin{array}{l}\text { Kiriri/Cariri, Kaimbé } \\
\text { Cariri-Cimbre }\end{array}$ \\
\hline
\end{tabular}




\begin{tabular}{|c|c|c|c|}
\hline & $\begin{array}{l}\text { Nossa Senhora da } \\
\text { Trindade } \\
\text { Santa Trindade }\end{array}$ & & \\
\hline Massarandupió & $\begin{array}{l}\text { Santo Antonio de } \\
\text { Arguim }\end{array}$ & $\begin{array}{l}\text { Jesuítas } \\
\text { Carmelitas Descalços }\end{array}$ & Tupi ou Tupinambá \\
\hline Missão do Sai & - & - & - \\
\hline Natuba & $\begin{array}{l}\text { Nossa Senhora da } \\
\text { Conceição }\end{array}$ & Jesuítas & Kiriri \\
\hline $\begin{array}{l}39 . \quad \text { Pacatuba [Patacuba] } \\
\text { Poxim }[\text { Pocbim] } \\
\text { Vila Nova }\end{array}$ & $\begin{array}{l}\text { Espírito Santo } \\
\text { São Félix de } \\
\text { Cantalice }\end{array}$ & $\begin{array}{l}\text { Capuchinhos } \\
\text { franceses } \\
\text { Carmelitas Descalços } \\
\text { Capuchinhos italianos }\end{array}$ & $\begin{array}{l}\text { Cajagôs [Caxagos, Caxagós] } \\
\text { Caboclos } \\
\text { Karapatós [carapatós, carapatos, } \\
\text { parapatos] }\end{array}$ \\
\hline Paigui & Santa Cruz & & \\
\hline Palmares & Santo Amaro & Franciscanos & $\begin{array}{l}\text { Caeté } \\
\text { Caboclos }\end{array}$ \\
\hline $\begin{array}{l}\text { 42. Pambu [Nambu, Gambu, Pomba] } \\
\text { Ilha do Pambu }\end{array}$ & $\begin{array}{l}\text { Nossa Senhora da } \\
\text { Conceição }\end{array}$ & $\begin{array}{l}\text { Capuchinhos } \\
\text { bretões/franceses } \\
\text { Carmelitas Descalços } \\
\text { Capuchinhos } \\
\text { Italianos }\end{array}$ & $\begin{array}{l}\text { Procás e Brancarurus } \\
\text { Cariri (Ba) } \\
\text { Tamaqueú/ } \\
\text { Cariri (Pe) }\end{array}$ \\
\hline 43. $\quad$ Penedo & & $\begin{array}{l}\text { Capuchinhos } \\
\text { franceses }\end{array}$ & Carapátios \\
\hline Porta das Missões & & Capuchinhos & \\
\hline $\begin{array}{l}45 . \quad \text { Porto da Folha } \\
\text { (Sergipe) } \\
\text { Vila de Traipu ou S. Pedro do Pôrto da } \\
\text { Folha }\end{array}$ & São Pedro & $\begin{array}{l}\text { Capuchinhos } \\
\text { bretões/franceses } \\
\text { Capuchinhos italianos }\end{array}$ & $\begin{array}{l}\text { Aramurus [Urumarus, } \\
\text { Aramarus, Oromarais] } \\
\text { Cariri }\end{array}$ \\
\hline 46. $\quad$ Rio de Contas & & Capuchinhos italianos & \\
\hline Rio Real & Jesus, Maria, José & Carmelitas & $\begin{array}{l}\text { Procás } \\
\text { Kiriri }\end{array}$ \\
\hline Rodelas & São João Batista & $\begin{array}{l}\text { Capuchinhos } \\
\text { franceses } \\
\text { Franciscanos } \\
\text { Jesuítas } \\
\text { Capuchinhos italianos }\end{array}$ & $\begin{array}{l}\text { Porcáz [Proká, Procá, Porcacás] } \\
600 \text { Índios } \\
\text { Procárodela }\end{array}$ \\
\hline Saco dos Morcegos & $\begin{array}{ll}\text { Ascensão } & \text { de } \\
\text { Cristo/Nossa } & \\
\text { Senhora } & \text { da } \\
\text { Ascensão } & \\
\end{array}$ & Jesuítas & Kiriri/Cariri \\
\hline 50. & $\begin{array}{l}\text { Nossa Senhora das } \\
\text { Neves }\end{array}$ & Franciscanos & Cariri-Cimbre \\
\hline Salitre & $\begin{array}{l}\text { Nossa Senhora } \\
\text { Madre de Deus } \\
\text { São Gonçalo }\end{array}$ & $\begin{array}{l}\text { Clérigos } \\
\text { Franciscanos }\end{array}$ & Cariri \\
\hline $\begin{array}{ll}52 . & \text { Santo Antônio da Aldeia / Santo } \\
\text { Antônio } & \end{array}$ & Santo Antônio & $\begin{array}{l}\text { Clérigos } \\
\text { Franciscanos }\end{array}$ & \\
\hline São Francisco Xavier de Jacobina & & & \\
\hline 54. Una ou Iguma & São Miguel & & \\
\hline $\begin{array}{l}55 . \quad \text { Vargem [V }[\text { arge, Vargé,V Varze] }] \\
\text { Ilha da Vargea }\end{array}$ & $\begin{array}{l}\text { B. Serafim de } \\
\text { Montegranário }\end{array}$ & $\begin{array}{l}\text { Capuchinhos } \\
\text { franceses } \\
\text { Carmelitas Descalços } \\
\text { Capuchinhos } \\
\text { Italianos } \\
\end{array}$ & $\begin{array}{l}\text { Cariri } \\
\text { Procás [Porcáz, Porcacazes, } \\
\text { Borcás, Porcá, Porcacáz, Porcacaes, } \\
\text { Preguez, Porus] } \\
\text { Brancarurus (Tapuia) }\end{array}$ \\
\hline $\begin{array}{l}56 . \quad \text { Zorobabé/ } \\
\text { Sorobabé }\end{array}$ & & & Carurus \\
\hline
\end{tabular}

Quadro 3 - Aldeamentos e missões da Bahia, séculos XVII-XVIII (Fonte: Carneiro, 2013) ${ }^{16}$

${ }^{16}$ As fontes nas quais Carneiro (2013) se baseou foram: Dantas et al (1992); Puntoni (2002, p. 295-299); Pompa (2003, p. 304-305), Pompa (2001, 2004, 2011); Silva (1989) e Regni (1988). 
Fonte: Dantas et al (1992); Puntoni (2002, p. 295-299); Pompa (2003, p. 304-305); Silva (1989) e Regni (1988).

\section{CONSIDERAÇÕES FINAIS}

Do que foi apresentado aqui a respeito da inserção do indígena na escrita portuguesa, destacamos, resumidamente, para concluir, o seguinte:

a) A maioria dos indígenas entendia e falava o português na nova Vila de Abrantes no século XVIII; poucos sabiam ler e escrever, todavia, e os que eram alfabetizados se tratavam de mestiços;

b) Oito mamelucos alfabetizados assumiram cargos na administração da nova Vila de Abrantes, havendo registros de assinatura de cinco deles em petição reivindicando terras.

Trata-se não de indícios, mas da existência comprovada de indígenas alfabetizados no litoral baiano, nos setecentos.

Apresentamos neste texto - para além desses fatos no litoral - caminhos para o estudo da inserção do indígena na escrita portuguesa, nos sertões baianos. É possível, a nosso ver, encontrar fontes produzidas por indígenas escolarizados, a partir do século XVII, na região do semiárido, na área do Rio São Francisco e das Jacobinas e em áreas vizinhas, onde houve aldeamentos (listados por Carneiro (2013)), nos seiscentos e setecentos, organizados, segundo detalhamento de Pompa (2001, 2003), à maneira dos aldeamentos do litoral.

Os caminhos estão aí para serem percorridos, para a história do português popular brasileiro. E, como disse Mattos e Silva (2002, p. 464), "O trabalho será muito, de muitos, e não será por pouco tempo”. Nessas breves linhas, nossa contribuição.

\section{FONTES CONSULTADAS}

AHU - Arquivo Histórico Ultramarino. Projeto Resgate - 2 de janeiro de 1799, doc. Com anexo sobre quilombos denominados de Andrahi, o de Tupim e Crobó, falam da intenção de acabar com esses quilombos -AHU - Baía, cx. 212, doc. 14951.

AHU - Arquivo Histórico Ultramarino. Projeto Resgate - 23/04/1722 - Carta patente assinada pelo vice-rei, sobre guerra ao gentio bárbaro e aos negros fugidos -AHU - Baía, cx. 16, doc. 1420 .

AHU - Arquivo Histórico Ultramarino. Projeto Resgate - 1710, Junho, 21, Bahia. Letra de Câmbio passada pelo escrivão do Tesouro Real da Bahia Antonio Alves, referente aos escravos vindos da Costa da Mina. AHU - Baía, cx. 6, doc. 35. 
AHU - Arquivo Histórico Ultramarino. Projeto Resgate - 1758, Maio, 19, Lisboa. Carta Régia (minuta) do rei [D. José] ao arcebispo da Bahia [José Botelho de Matos] e vice-rei e governador-geral do Brasil, conde dos Arcos, Marcos de Noronha comunicando a instituição do tribunal da Relação da Bahia para averiguar os bens dos religiosos jesuítas e a criação de vilas nos antigos aldeamentos. AHU - Baía, cx. 144, doc. 26.

AHU - Arquivo Histórico Ultramarino. Projeto Resgate - 1770, Maio, 8, Porto Seguro. Oficio do desembargador ouvidor do Porto Seguro, José Xavier Machado Monteiro, ao [secretário de estado da Marinha e Ultramar, Francisco Mendonça Furtado], referente à medida que tomou relativamente aos índios mais jovens, tirando-as da companhia dos pais, obrigando-os a conviver com os brancos, bem como às vilas que erigiu e ao pedido de sucessor para seu cargo. AHU - Baía, cx. 169, doc.41.

APEB - Arquivo Público do Estado da Bahia. Seção Colonial - Maço 603: Dossiê sobre aldeamentos e Missões indígenas. 1758-1759. Caderno 1. Lista de todos os índios de Abrantes - Relação de todos que sabiam falar e escrever, s/d.; Caderno 11. Notícia sobre a criação de vilas nas aldeias dos índios, 1758/1759; Caderno 13. Estabelecimento de vilas nas aldeias dos índios, 1758; Caderno 14. Instruções para a criação de vilas. Relação das aldeias indígenas que deveriam ser elevadas a vilas, com os nomes que adotariam e a relação de ministros que foram erigir e demarcar, s/d.; Caderno 21. Instrução para elevar a vila às aldeias dos índios. 1758; Caderno 24. Relação das aldeias de índios que foram estabelecidas como vilas, 1758; Caderno 25. Petição dos moradores de Vila Nova de $\underline{\text { Abrantes, }}$ referente à falta de rendas para a Câmara - Despacho para o Juiz de Fora, 1758; Caderno 28. Petição ao Tribunal do Conselho Ultramarino: Pedro Reis, Francisco Lopes, Antônio Borges, Jerônimo Albuquerque a propósito das terras da Câmara da Vila Nova de Abrantes, 1759.

\section{REFERÊNCIAS BIBLIOGRÁFICAS}

ALMEIDA, M. R. C. Os índios aldeados no Rio de Janeiro Colonial: novos súditos cristãos do império português. 2000. 351f. Tese (doutorado em Antropologia) - Universidade Estadual de Campinas, Campinas, 2000.

ALMEIDA, M. R. C. Os índios aldeados: histórias e identidades em construção. Tempo, Rio de Janeiro, v.6, n.12, p.51-71, jul. 2001.

BRUNET, L. C. De aldeados a súditos: viver, trabalhar e resistir em Nova Abrantes do Espírito Santo Bahia 1758-1760. 2008. Dissertação (Mestrado em História) Universidade Federal da Bahia, Salvador, 2008. 
CARNEIRO, Z. O. N.; ALMEIDA, N. L. F. Elementos para uma sócio-história do semiárido baiano. In: RAMOS, J. M.; ALKMIM, M. A. (Org.). Para a História do Português Brasileiro: estudos sobre mudança linguística e história social. Belo Horizonte: Faculdade de Letras da UFMG, 2007 [2002]. p. 423-442.

CARNEIRO, Z. O. N. Estudo de escolarização de aldeados no Brasil do século XVII: um caminho para a compilação de possíveis fontes escrita em português por "Tapuia"/Projeto 3 - História do português brasileiro - desde a Europa até a América, sob a coordenação de Afrânio Barbosa e de Célia Lopes (http://www.mundoalfal.org/Projeto3.pdf). In: XV CONGRESSO INTERNACIONAL DE LA ASOCIACIÓN DE LINGÜÍSTICA Y FILOLOGÍA DE AMÉRICA LATINA. 2008. Montevideo. Libro de resúmenes de XV Congresso Internacional de La Asociación de Lingüistica y Filología de América Latina/ALFAL. Montevideo: ALFAL, 2008. p. 263-263.

CARNEIRO, Z. O. N. Vozes do sertão em dados: história, povos e formação do português brasileiro. In: VI Feira do Semi-Árido: desertificação, perspectivas de autonomia produtiva frente aos desafios socioambientais. Feira de Santana, 2008.

CARNEIRO, Z. O. N. Escolarização de aldeados no Brasil dos séculos XVII e XVIII: um espaço de gestação de uma produção escrita indígena?. In: VI Congresso Internacional da Associação Brasileira de Lingüistica - ABRALIN. João Pessoa, mar. 2009.

CARNEIRO, Z. O. N. Sobre a produção escrita atribuída aos indígenas na Vila de Abrantes em 1758. 2011. (Apresentação de Trabalho/Comunicação). Anais do VII Congresso Internacional da ABRALIN. Curitiba, 2011. Disponível em: http://abralin.org/site/publicacao-em-anais/abralin-curitiba-2011/. Acesso em: dez. 2012.

CARNEIRO, Z. O. N. Escolarização de aldeados no Brasil dos séculos XVII e XVIII: um espaço de gestação de uma produção escrita indígena?. In: MATTOS E SILVA, R. V.; OLIVEIRA, K.; AMARANTE, J. (Org.). Várias Navegações: português arcaico, português brasileiro, cultura escrita no Brasil, outros estudos. Salvador: EDUFBA, 2013. p. 55-76.

CARNEIRO et al. O português geral brasileiro nos sertões baianos seiscentistas: indícios sobre a participação indígena (no prelo).

CARVALHO JÚNIOR, A. D. Índios cristãos - a conversão dos gentios na Amazônia portuguesa (1653-1769). 2005. 407 f. Tese (doutorado em História) - Universidade Estadual de Campinas, Campinas, 2005. 
CARVALHO JÚNIOR, A. D. Principais indígenas na Amazônia portuguesa. In: XXIII SIMPÓSIO NACIONAL DE HISTÓRIA. 2005, Londrina. Anais do XXIII Simpósio Nacional de História: História: Guerra e Paz. Londrina: ANPUH, 2005. cd rom.

CASTELNAU-L'ESTOILE, C. Operários de uma vinha estéril: os jesuítas e a conversão dos índios no Brasil - 1580-1620. Trad. de Ilka Stern Cohen. Bauru: EDUSC, 2006.

DANTAS, B. G. et al. Os povos indígenas no Nordeste brasileiro: um esboço histórico. In: CUNHA, M. C. (Org.). História dos índios no Brasil. São Paulo: Companhia das Letras; Secretaria Municipal de Cultura: FAPESP, 1992. p. 431-456.

GONÇALVES, C. R. Os Potiguara na guerra dos brancos (1630-1654). In: XXIII SIMPÓSIO NACIONAL DE HISTÓRIA. 2005. Londrina. Anais XXIII Simpósio nacional de história: História: Guerra e Paz. Londrina: Editorial Mídia, 2005.

HULSMAN, L. Índios do Brasil na república dos países baixos: as representações de Antônio Paraupaba para os Estados Gerais em 1654 e 1656. (U.V.A. Amsterdã). In: Revista de História $\mathrm{n}^{\mathrm{o}} 154$ (Terceira Série) - $1^{\circ}$ semestre de 2006, p. 214-278.

LEITE, S. J. S. História da Companbia de Jesus no Brasil. Lisboa: Portugália; Rio de Janeiro: Civilização Brasileira, 1938-1950.

LUCCHESI, D. Variação e norma: elementos para uma caracterização sociolinguística do português do Brasil. Revista Internacional de Lingua Portuguesa, Lisboa, v. 12, p. 17-28, 1994.

LUCCHESI, D. As duas grandes vertentes da história sociolinguística do Brasil (15002000). DELTA, São Paulo, v.17, n.1, p. 97-132, 2001.

MAGALHÃES, P. A. I. "Equus Rusus": A Igreja Católica e as Guerras Neerlandesas na Bahia. 2010. Tese (Doutorado em História) - Universidade Federal da Bahia, Salvador, 2010.

MATTOS E SILVA, R. V. Para a história do português culto e popular brasileiro: sugestões para uma pauta de pesquisa. In: Alkmim, T. M. Para a história do português brasileiro: novos estudos. São Paulo. Humanitas/FFCHL/USP:FAPESP, v.3, 2002. p. 443464.

MATTOS E SILVA, R. V. De fontes sócio-históricas para a história social lingüística do Brasil: em busca de indícios. In: MATTOS E SILVA, Rosa Virgínia (Org.). Para a história do português brasileiro: primeiros estudos. São Paulo: Humanitas/FFCHL/USP:FAPESP, v.2, t. 2, 2001. p. 275-302. 
MATTOS E SILVA, R. V. Para a história do português culto e popular brasileiro: sugestões para uma pauta de pesquisa. Cadernos de Letras da UFF - Dossiê: Literatura, língua e identidade, n. 34, p. 11-30, 2008. Disponível em: < http://www.uff.br/cadernosdeletrasuff/34/artigo1.pdf $\geq$. Acesso em: 23 de dez. 2008.

MATTOSO, K. M. Q. Babia, Século XIX: uma província no Império. Rio de Janeiro: Editora Nova Fronteira, 1992.

MONTEIRO, J. M.. Os Guarani e a história do Brasil meridional: séculos XVI-XVII. In: CUNHA, M. C. (Org.). História dos indios no Brasil. São Paulo: Companhia das Letras; Secretaria Municipal de Cultura: FAPESP, 1992. p. 475-498.

MONTEIRO, J. M. Negros da terra: índios e bandeirantes nas origens de São Paulo. São Paulo: Companhia das Letras, 1994a.

MONTEIRO, J. M. (Org.). Guia de fontes para a história indígena e do indigenismo em arquivos brasileiros. São Paulo: NHII-USP, 1994b.

MONTEIRO, J. M. $A$ dança dos números: a população indígena do Brasil desde 1500. Rio de Janeiro: Tempo e Presença, 1995.

MONTEIRO, J. M.. Tupis, Tapuias e historiadores: estudos de história indígena e do indigenismo. Tese de livre docência. Departamento de Antropologia, Instituto de Filosofia e Ciências Humanas, Universidade Estadual de Campinas. Campinas, 2001. Disponível em <http://www.ifch.unicamp.br/ihb/estudos/TupiTapuia.pdf>. Acesso em: 28 abr. 2012.

NEUMANN, E. S. Mientras volaban correos por los pueblos: autogoverno e práticas letradas nas missões guarani, século XVIII. Horizontes Antropológicos, Porto Alegre, n. 22, p. 93-119, dez. 2004.

NEUMANN, E. S. Práticas letradas guaranis: produção e usos da escrita indígena (séculos XVII e XVIII). 2005. Tese (doutorado em História Social) - Universidade Federal do Rio de Janeiro, Rio de Janeiro, 2005.

NEUMANN, E. S. Escribiendo en la frontera del Paraguay: prácticas de la escritura indígena durante la demarcación de limites (siglo XVIII). Cultura escrita \& sociedad, v. 7, p. 159-190, 2008.

NEUMANN, E. S. De letra de índio: cultura escrita e memória indígena nas reduções do Paraguai. Varia Historia, Belo Horizonte, v. 41, p. 177-196, 2009. 
NEUMANN, E. S.; RIBEIRO, M. R. A evangelização falada e escrita: notas sobre escrita e oralidade eclesiástica no Brasil do século XVIII. Revista Memória em Rede, Pelotas, v. 7, p. 113-129, 2015.

NEUMANN, E. S. Práticas de escrita indígena nas reduções no século XVIII. In: QUEVEDO, J. Missões: reflexões e questionamentos. Santa Maria: Caxias, 2016. p. 123144.

POMPA, M. C. Religião como tradução: missionários, Tupi e 'Tapuia' no Brasil Colonial. 2001. 453 f. Tese (Doutorado em Ciências Sociais) - Universidade Estadual de Campinas, Campinas, 2001.

POMPA, M. C. Religião como Tradução: missionários, Tupi e "Tapuia” no Brasil colonial. Bauru: EDUSC, 2003.

POMPA, M. C. O profetismo Tupi-Guarani: a construção de um objeto antropológico. Revista de Indias, Madrid, vol. LXIV, p. 141-174, 2004.

POMPA, C. Conversões indígenas: poder simbólico e razão prática no sertão colonial. In: AGNOLIN, A.; Wissembach, M. C. C.; SOUZA M. M.; ZERON, C. (Org.). Contextos Missionários: Religião e Política no Império Português. São Paulo: Hucitec, 2011. p. 86109.

PRIMITIVO MOACYR. A instrução e o império: subsídios para a história da educação no Brasil (1854-1888). São Paulo: Nacional, 1937.

PRIMITIVO MOACYR. A instrução e o império: subsídios para a história da educação no Brasil (1835-1889). São Paulo: Nacional, 1939.

PROJETO RESGATE DE DOCUMENTAÇÃO HISTÓRICA BARÃO DO RIO BRANCO/Arquivo Histórico Ultramarino/AHU/Base de dados/UEFS, Laboratório de História. Disponível em: < http://www.cmd.unb.br/resgate_ahu.php >. Acesso em 05 set. 2010.

PROJETO VOZES DO SERTÃO EM DADOS: história, povos e formação do português brasileiro. FASE 1- Coordenação: Zenaide de Oliveira Novais Carneiro. Disponível em: <www.uefs.br/nelp>. Acesso em 05 ago. 2012.

PUNTONI, P. A Guerra dos bárbaros: povos indígenas e a colonização do sertão do nordeste do Brasil, 1650-1720. São Paulo: Hucitec, 2002.

REGNI, P. V. Os Capuchinhos na Babia: os Capuchinhos Franceses. Trad. Fr. Agatângelo de Crato. Caxias do Sul: Edições Paulinas, 1988. 
SANTOS, E. G. O diretor de indios: análise preliminar dos diretores parciais das aldeias indígenas: Bahia, 1845-1889. 1988. Dissertação (Mestrado em Ciências Sociais) Universidade Federal da Bahia, Salvador, 1988.

SANTOS, F. L. Te Deum Laudamos: a expulsão dos jesuítas da Bahia (1758-1763). 2002. Dissertação (Mestrado em História) - Universidade Federal da Bahia, Salvador, 2002.

SANTOS, F. L. Da catequese à civilização: colonização e povos indígenas na Bahia. (17501800). 2012. Tese (Doutorado em História)) - Universidade Federal da Bahia, 2012.

SANTOS, F. L. A civilização como missão: agentes civilizadores de índios na Bahia colonial no contexto da política pombalina. Tempo, Niterói, v. 22, n. 4, p.533-550, set.dez., 2016.

SIERING, F. C. Conquista e dominação dos povos indígenas: resistência nos sertões dos maracás, 1650-1701. 2008. Dissertação (Mestrado em História) - Universidade Federal da Bahia, Salvador, 2008.

SILVA JÚNIOR, A. B. Aldeando sentidos: os Xucuri-Kariri e o serviço de proteção aos índios no agreste alagoano. 2007. Dissertação (Mestrado em História) - Universidade Federal da Bahia, Salvador, 2007.

SILVA, S. C. B. M. Urbanização e metropolização no estado da Babia: evolução e dinâmica. Salvador: Centro Editorial e Didático da UFBA, 1989.

SILVA NETO, S. Introdução ao estudo da língua portuguesa no Brasil. Rio de Janeiro: Presença, 1986 [1950].

SOUZA, P. D. S. De todos que sabiam ler e escrever: em busca de fontes documentais para uma reconstrução da penetração das populações indígenas brasileiras no mundo da cultura escrita. Projeto de Tese em andamento (Doutorado em Linguística) Universidade Federal da Bahia, 2015.

SOUZA, P. D. S. LOBO, T. C. F. Da aplicação do Diretório Pombalino ao Estado do Brasil: povos indígenas e políticas linguísticas no século XVIII. A Cor das Letras, Feira de Santana, v. 17, n. 1, p. 46-59, 2016.

SPIX, J. B; MARTIUS, K. F. P. Através da Babia. Bahia: Imprensa Oficial, 1916.

VIEIRA, A. S. J. Escritos Instrumentais sobre os indios. (Org.) J. C. Sebe Bom Meihy. São Paulo: Educ/Loyola,1992. 
VILHENA, L. S. A Babia no século XVIII. Salvador: Editora Itapuã, 1969.

\section{ANEXOS}

Anexo 1 - Lista de documentos atribuídos a indígenas ou redigidos em português, a pedido, citados na historiografia (extraída de Carneiro, 2013).

Anexo 2 - Fac-símile apresentado por Hulsman (2006, p. 64), com uma amostra de Antonio Paraupaba (Extraído de Carneiro, 2013).

Anexo 3 - Formas textuais da escrita guarani missioneira (Neumann, 2005). (Extraído de Carneiro, 2013).

Anexo 1 - Lista de documentos atribuídos a indígenas ou redigidos em português, a pedido, citados na historiografia (extraído de Carneiro, 2013).

\begin{tabular}{|c|c|c|c|}
\hline $\begin{array}{l}\text { Natureza } \\
\text { Documento }\end{array}$ & $\begin{array}{l}\text { Local/ } \\
\text { Data }\end{array}$ & Resumo conteúdo & Fonte \\
\hline $\begin{array}{l}\text { Solicitações } \\
\text { consultas }\end{array}$ & $\begin{array}{l}\text { Maranhão1 } \\
\text { o de agosto } \\
\text { de } 1659 \\
\text { Maranhão } \\
12 \text { de } \\
\text { setembro } \\
\text { de } 1648 \\
3 \text { de } \\
\text { outubro de } \\
1648\end{array}$ & $\begin{array}{l}\text { Solicitação ao Conselho Ultramarino de } \\
\text { mercê do hábito de Cristo e terça } \\
\text { correspondente por serviços prestados à } \\
\text { Coroa Portuguesa/ } \\
\text { Jorge Tajaibuna } \\
\text { (Principal da aldeia Camucy) } \\
\text { Solicitação a Conselho Ultramarino de mercê } \\
\text { de Hábito de Cristo, Dois principais das } \\
\text { aldeias de Tapuitapera e Sergipe } \\
\text { Solicitação de mercês, Antonio, filho do } \\
\text { Principal Marcos da Costa (Principal da } \\
\text { Aldeia Tabajara) Antonio, filho do Principal } \\
\text { Marcos da Costa (Principal da Aldeia } \\
\text { Tabajara) }\end{array}$ & $\begin{array}{l}\text { Carvalho Jr. (2005) } \\
\text { AHU, Maranhão, 009, } \\
\text { cx 3. D. } 266 . \\
\text { AHU, Maranhão, 009, } \\
\text { cx 3. D. } 268 . \\
\text { AHU, Maranhão, 009, } \\
\text { cx 3. D. } 268 .\end{array}$ \\
\hline Cartas & & Referências a raras cartas de lideranças nativas & $\begin{array}{l}\text { J. M. Monteiro, } \\
\text { prefácio, p. 17. In. } \\
\text { Pompa (2001) }\end{array}$ \\
\hline $\begin{array}{l}\text { Requerimentos } \\
\text { diversos }\end{array}$ & $\begin{array}{l}13 \text { de } \\
\text { janeiro de } \\
1650 \\
9 \text { de abril } \\
\text { de } 1650\end{array}$ & $\begin{array}{l}\text { Requerimento de Manoel de Jesus e Souza, } \\
\text { Capitão-Mor de São Lourenço, destacando os } \\
\text { serviços prestados por sua aldeia. } \\
\text { Dois requerimentos do filho de Araribóia que } \\
\text { se encontrava em Lisboa, solicitando } \\
\text { benefícios por sua condição de súdito } \\
\text { indígena, filho de personagem notório, no } \\
\text { qual foi atendido. }\end{array}$ & $\begin{array}{l}\text { Almeida (2001, p. 57) } \\
\text { AHU - Documentos } \\
\text { avulsos do Rio de } \\
\text { Janeiro. CX. 162, doc. } \\
2 .\end{array}$ \\
\hline
\end{tabular}




\begin{tabular}{|c|c|c|c|}
\hline & $\begin{array}{l}2^{\text {a }} \text { metade } \\
\text { do século } \\
\text { XVIII }\end{array}$ & $\begin{array}{l}\text { Requerimento do Capitão-Mor da aldeia de } \\
\text { Itaguaí, José Pires Tavares, à rainha D. Maria } \\
\text { I. }\end{array}$ & $\begin{array}{l}\text { Almeida (2001:62). } \\
\text { Revista do IHGB, } \\
\text { Tomo XV, 1854, 353- } \\
358 .\end{array}$ \\
\hline $\begin{array}{l}\text { Petição dos } \\
\text { Índios da Vila } \\
\text { Nova de } \\
\text { Abrantes } \\
\text { reivindicando } \\
\text { as Terras da } \\
\text { Capivara. }\end{array}$ & $\begin{array}{l}\text { Bahia, } 9 \text { de } \\
\text { dezembro } \\
\text { de } 1758\end{array}$ & $\begin{array}{l}\text { Consulta ao rei D. José, acerca de } \\
\text { requerimento dos índios moradores da vila de } \\
\text { Nova Abrantes, solicitando professores, } \\
\text { ajuda de custo para vestuário, funcionários } \\
\text { administrativos e judiciários, além de } \\
\text { reformas de antigos prédios jesuíticos, etc }{ }^{17} \text {. } \\
\text { Petição dos moradores de Vila Nova de } \\
\text { Abrantes, referente à falta de rendas para a } \\
\text { Câmara - Despacho para o Juiz de Fora, } \\
\text { 1758. } \\
\text { Petição aribunal do Conselho } \\
\text { Ultramarino: Pedro Reis, Francisco Lopes, } \\
\text { Antônio Borges, Jerônimo Albuquerque a } \\
\text { propósito das terras da Câmara da Vila Nova } \\
\text { de Abrantes, 1759. }\end{array}$ & $\begin{array}{l}\text { AHU Baía, cx. 146, } \\
\text { doc. 40; cx. 147, doc. } \\
\text { 85/AHU ACL CU } \\
\text { 005. Cx. 138, d. } \\
\text { 106.675. } \\
\\
\text { Brunet (2008) - APEB } \\
\text { - Maço 603. Dossiê } \\
\text { sobre aldeamentos e } \\
\text { Missões indígenas. } \\
\text { 1758-1759. } \\
\text { Caderno 25 } \\
\text { Caderno } 28 .\end{array}$ \\
\hline
\end{tabular}

Fonte: Almeida (2000); Pompa (2001); Carvalho Jr. (2005) e Brunet (2008).

Anexo 2 - Fac-símile apresentado por Hulsman (2006:64), com uma amostra de Antonio Paraupaba

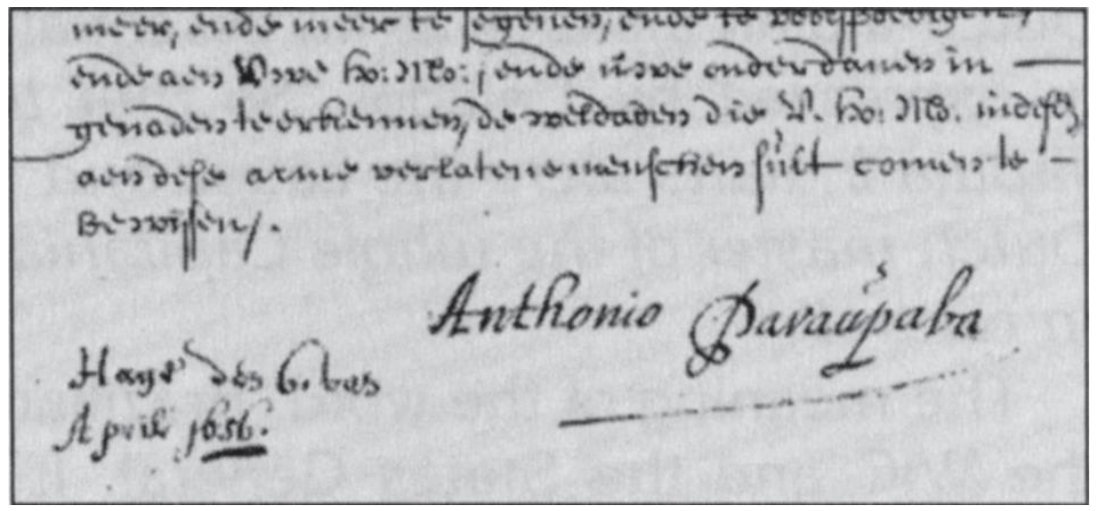

Fonte: Carneiro (2013).

${ }_{17}$ Quase cem anos depois, dados como esses constam ainda no relatório de um Inspetor, escrito em 1852 (cf. Primitivo Moacyr, 1937, 1939): "No antigo regime era costume criarem-se cadeiras primarias nas localidades em que estabeleciam índios novamente convertidos. Se nos não convém ir procurar novos índios ás florestas para os converter e civilizar, nem mesmo olharmos de perto para a instrução dos aldeamentos, é de necessidade atendermos ao menos a essa outra classe, que, entremeada com a população livre, tem ela uma ação desmolarizadora, que não procuramos remediar. Quero crer perigoso dar-se-lhe instrução, mas porque não se lhe dar uma educação moral e religiosa". 
Anexo 3 - Formas textuais da escrita guarani missioneira (Neumann, 2005)

\begin{tabular}{|c|c|c|}
\hline $\begin{array}{l}\text { Modalidade } \\
\text { textual }\end{array}$ & Característica geral & Período verificado \\
\hline Bilhete & $\begin{array}{l}\text { Documento de difícil conservação, } \\
\text { geralmente mensagens trocadas entre } \\
\text { indígenas que apresentam uma escrita } \\
\text { informal, por vezes sem data, destinatário } \\
\text { nem remetente. }\end{array}$ & $\begin{array}{l}\text { Momentos de agitação, quando os Guarani procuram } \\
\text { comunicar-se pela via escrita. (século XVII - década de } \\
60-\text {, e meados do século XVIII, quando "voavam os } \\
\text { bilhetes"). }\end{array}$ \\
\hline Carta & $\begin{array}{l}\text { Escrita voltada à comunicação com a } \\
\text { sociedade colonial, relacionada às regras } \\
\text { epistolográficas cultas e caligráficas. }\end{array}$ & $\begin{array}{l}\text { A partir de meados do século XVIII, prolongando-se à } \\
\text { segunda metade. }\end{array}$ \\
\hline Memorial & $\begin{array}{l}\text { Voltado a expressar uma demanda } \\
\text { extraordinária, com escrita ajustada para } \\
\text { atingir uma determinada audiência. }\end{array}$ & $\begin{array}{l}\text { Demandas apresentadas através dessa via são mais } \\
\text { frequentes na segunda metade do século XVIII, mas há } \\
\text { evidência anterior (1742). }\end{array}$ \\
\hline Diário & $\begin{array}{l}\text { Modalidade caracterizada pela anotação, } \\
\text { geralmente diária e imediata aos } \\
\text { acontecimentos. O redator costuma } \\
\text { manifestar suas impressões pessoais. } \\
\end{array}$ & $\begin{array}{l}\text { Até o momento apenas foram localizados dois textos com } \\
\text { essa característica, um de } 1702 / 1704 \text { e outro de } \\
1752 / 1754 \text {. }\end{array}$ \\
\hline $\begin{array}{l}\text { Relato } \\
\text { pessoal }\end{array}$ & $\begin{array}{lcc}\begin{array}{l}\text { Procura estabelecer uma } \\
\text { determinados }\end{array} \text { fatos } & \begin{array}{c}\text { memória de } \\
\text { vivenciados }\end{array} \\
\text { coletivamente. } & & \end{array}$ & $\begin{array}{l}\text { Textos com essa característica são raros, a relação de } \\
\text { Nerenda é o principal exemplar conhecido. Há uma carta } \\
\text { de Primo Ybarenda que pode ser enquadrada nesse } \\
\text { gênero. Ambos os textos correspondem ao período de } \\
\text { conflito nas reduções. }\end{array}$ \\
\hline $\begin{array}{l}\text { Ata } \\
\text { cabildo }\end{array}$ & $\begin{array}{l}\text { Anotação resumida dos temas tratados nas } \\
\text { sessões dos cabildos. }\end{array}$ & $\begin{array}{l}\text { São consideradas tardias nas reduções e apenas existem } \\
\text { informações para a segunda metade do XVIII. }\end{array}$ \\
\hline $\begin{array}{l}\text { Escrita } \\
\text { exposta: } \\
\text { cruzes, } \\
\text { cartazes } \\
\end{array}$ & $\begin{array}{l}\text { Modalidade voltada para a comunicação } \\
\text { pública, utilizada em espaço aberto, visando } \\
\text { uma leitura à distância. }\end{array}$ & $\begin{array}{l}\text { Utilizada pelos jesuítas no início da catequese e apropriada } \\
\text { pelos Guarani para demarcar território como mensagem } \\
\text { com caráter de ultimato. }\end{array}$ \\
\hline $\begin{array}{l}\text { Narrativa } \\
\text { histórica }\end{array}$ & 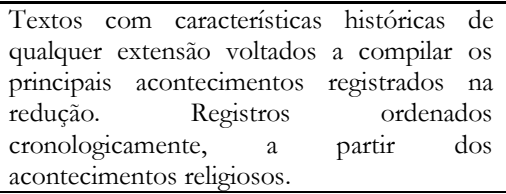 & Essas obras são dadas como perdidas. \\
\hline
\end{tabular}

Fonte: Carneiro (2013).

Recebido em: 02/05/2017

Aprovado em: 08/08/2017

Publicado em: 01/12/2017 